\title{
The dawn of phylogenetic research on Neotropical fishes: a commentary and introduction to Baskin (1973), with an overview of past progress on trichomycterid phylogenetics
}

\author{
Mário C. C. de Pinna
}

A review is made of the impact of the landmark Ph. D. Thesis of Jonathan N. Baskin from 1973 on the development of the phylogenetics of catfishes and some of its main subgroups and on neotropical ichthyology in general. Baskin's work is the first to propose a hypothesis of relationships for loricarioid catfishes and for the family Trichomycteridae on the basis of explicit Hennigian principles. It is arguably also the first application of phylogenetic methods to any group of neotropical fishes. The hypotheses presented by Baskin covered the monophyly of Siluriformes, the monophyly and relationships of loricarioid families and the relationships of Trichomycteridae (including the monophyly of the family and the relationships among its constituent genera). His discoveries are analyzed in view of the subsequent 40 -odd years of progress on the understanding of the phylogeny of the respective groups. The ideas proposed in 1973 have resisted the test of time remarkably well, and a majority of them have been corroborated by additional characters and taxa (including molecular data and several taxa newly discovered in the meantime), as well as by modern quantitative analysis.

Um ensaio é realizado sobre o impacto da tese de doutorado pioneira de 1973 de Jonathan N. Baskin no desenvolvimento do conhecimento filogenético de Siluriformes e alguns dos seus principais subgrupos e na ictiologia neotropical em geral. O trabalho de Baskin é o primeiro a propor uma hipótese de relações para os bagres loricarioides e para a família Trichomycteridae com base em princípios Hennigianos explícitos. Provavelmente é também a primeira implementação de métodos filogenéticos em qualquer grupo de peixes de água doce neotropicais. As hipóteses apresentadas por Baskin cobrem o monofiletismo de Siluriformes, o monofiletismo e as relações filogenéticas das famílias de Loricarioidea, e as relações filogenéticas de Trichomycteridae (incluindo o monofiletismo da família e as relações entre seus gêneros constituintes). Suas descobertas são analisadas à luz dos mais de 40 anos de progresso no entendimento da filogenia dos respectivos grupos. As ideias propostas em 1973 resistiram ao teste do tempo bastante bem e a maioria delas foi corroborada por caracteres ou táxons adicionais (incluindo dados moleculares e muitos táxons descobertos no interim), assim como por análises quantitativas mais modernas.

Keywords: Candiru, Cladistics, Catfishes, Siluriformes, Trichomycteridae.

"An overall objective of this work is to define natural (i.e., monophyletic in the sense of Hennig, 1966) groups of siluriforms" Baskin (1973: 1)

\section{Introduction}

In the early 1970's, phylogenetic systematics, or cladistics, was a revolutionary new method at the cuttingedge of systematic research. Controversy concerning cladistics reigned in professional circles and professional meetings, as cladists struggled to make Hennig (1966) the accepted standard in systematics. As normally in such paradigm shifts, it was impossible to predict the trajectory of the field. Application of phylogenetic methods was hotly debated in the community of professional systematists, in the eye of the storm of theoretical wars then in full charge (Hull, 1988). Leading authorities of the systematic and evolutionary establishment of the time were vociferously against phylogenetics or cladistics (e.g., Mayr, 1969, 1974; Simpson, 1981). Generational change is in the end the real arbiter in such disputes and subsequent years have seen an overwhelming preponderance of the phylogenetic paradigm. But history in retrospective looks more linear than it actually is. One must remember how risky it is to take sides in such turbulent times, especially for graduate students just beginning their careers. Justly enough, explicitly phylogenetic contributions from those years are now considered as pioneering in their respective specialties. 
In the early 1970's, the American Museum of Natural History (AMNH) in New York was a boiling think tank of phylogenetic theory. Its Department of Ichthyology, particularly, was an epicenter for the new ideas in cladistics and biogeography, with figures such as Donn Rosen and Gareth Nelson among its research staff. Students, mostly enrolled in a joint program between the Museum and the City University of New York (CUNY), were a key element in the departmental brain machinery, thriving in the highvoltage intellectual environment. One needs simply to be reminded of names such as Richard Vari, Lynne Parenti and Ed Wiley to have an idea of the student body at the AMNH-CUNY ichthyology program in those days. One of the products of that think tank was Baskin (1973; Fig. 1), a Ph.D. Thesis written in 1972 (hence the cover date) and successfully defended in 1973. Baskin's work fully embraced the new phylogenetic paradigm and was highly influential as a guide for subsequent research on the relationships of catfishes (S1 - Available only as online supplementary file accessed with the online version of the article at http://www.scielo.br/ni). It provided a template of how to derive hypotheses of monophyly from characterstate distributions; how to delimit character-states from observed variation; how to determine inferences of polarity; how to correctly identify synapomorphy, symplesiomorphy and homoplasy; and finally how to translate phylogenetic hypotheses into a classification. All such procedures were seen in action as applied to a real group of fishes with bones, fins, teeth and similar realities in which ichthyologists relish. The thesis also included a chapter on evolutionary trends, a concession to neodarwinian orthodoxy apparently demanded by the graduate program at the time (J. Baskin pers. comm.). Even that section was still original, though, relying as it did on strict phylogenetic hypotheses as a. Because of Baskin (1973), the Neotropical catfish family Trichomycteridae has the privilege of being among the earliest fish subgroups to be targeted by phylogenetic systematics according to explicit Hennigian principles. Baskin's work has remained unpublished for decades and obviously its impact might have been higher had it been published shortly after completion. But despite the obvious drawback of being available only as a thesis document, it has acquired a life of its own in the literature. Baskin (1973) gradually became a mandatory reference in systematic and taxonomic studies on trichomycterids and other loricarioids, and often on other groups of catfishes as well. The work provided an explicit proposal about the monophyly of the Trichomycteridae, as well as hypotheses about the relationships among trichomycterid subfamilies and most of their constituent genera. It also included an analysis of the largest monophyletic subgroup of catfishes which is now universally accepted, the superfamily Loricarioidea (then suborder Loricarioidei, including the Trichomycteridae plus five other Neotropical families).

Why publicly releasing the work after so many years? Because it contains contributions of lasting value. In addition to original hypotheses on trichomycterid and loricarioid relationships, Baskin (1973) also proposes several concepts on catfish phylogeny which are now current. Other ideas about characters and taxa which were already part of common knowledge to experts on siluriforms were organized and enunciated for the first time in explicit phylogenetic terminology. Also, Baskin (1973) may well be the earliest research work to propose a phylogenetic hypothesis on any group of neotropical fishes based on explicitly Hennigian principles. Other potential candidates for such position exist (e.g., Farris, 1968; Nelson, 1969; Rosen, 1972), but none of those cite the work of Willi Hennig as the source of their theoretical standing, despite the application of some core principles which in retrospect can be considered as Hennigian. So, the original document of 1973 is simply too important to be left in thesis format alone. Citation of unpublished academic dissertations is problematic or not permitted in some journals, resulting in biases which do not reflect the actual evolution of a field. Editors of Neotropical Ichthyology agreed that the work should be made available into more permanent user-friendly format in the normal literature. Of course, a contribution written in 1973 will always be of that era, and some explanation is necessary in order to place it in a 2016 context.

Much has happened in the intervening years. Phylogenetic methodology has undergone substantial change and knowledge about trichomycterid diversity has increased dramatically. Still, through all this change, many of the hypothesis and observations presented in Baskin (1973) survived remarkably well; some unscathed, others in more or less modified, nuclear form. Others were replaced because of additional data, interpretation or analysis. The phylogenetic hypotheses in Baskin were proposed on the basis core principles of Hennig (1966), in nearly pure form, as applied to comparative morphological data. At that time, parsimony analysis was still in its infancy (cf. Farris, 1968), and had not yet hybridized with Hennigian phylogenetics. Although parsimony reasoning is evident in several instances in his text, Baskin's analysis is essentially non-quantitative. It focuses on individual hypotheses of monophyly, the search for sister-group relationships and the evidence identified for each of them. The discussions in Baskin (1973) orbit strongly on polarity inferences derived from outgroup comparisons and clear-cut considerations of homologues. Such tradition was solidified in those years (Nelson, 2009) and remains at the core of research on evolutionary patterns, though recently somewhat masked (but not replaced) by analyses more focused on resulting patterns than on associated hypotheses of homology. In this introduction I will go through the most important ideas in Baskin (1973), reviewing them from the perspective of the progress and changes which transpired in the past 40-odd years. This paper was written as a prologue and commentary to the associated release of Baskin (1973) in the Neotropical Ichthyology online archive. The original document of 1973 is reproduced in edited form as supplemental material. 


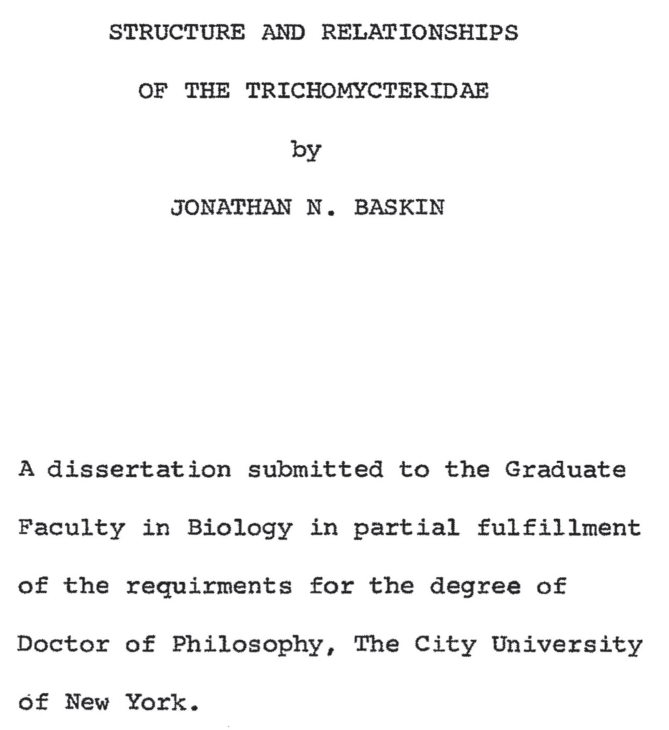

1972

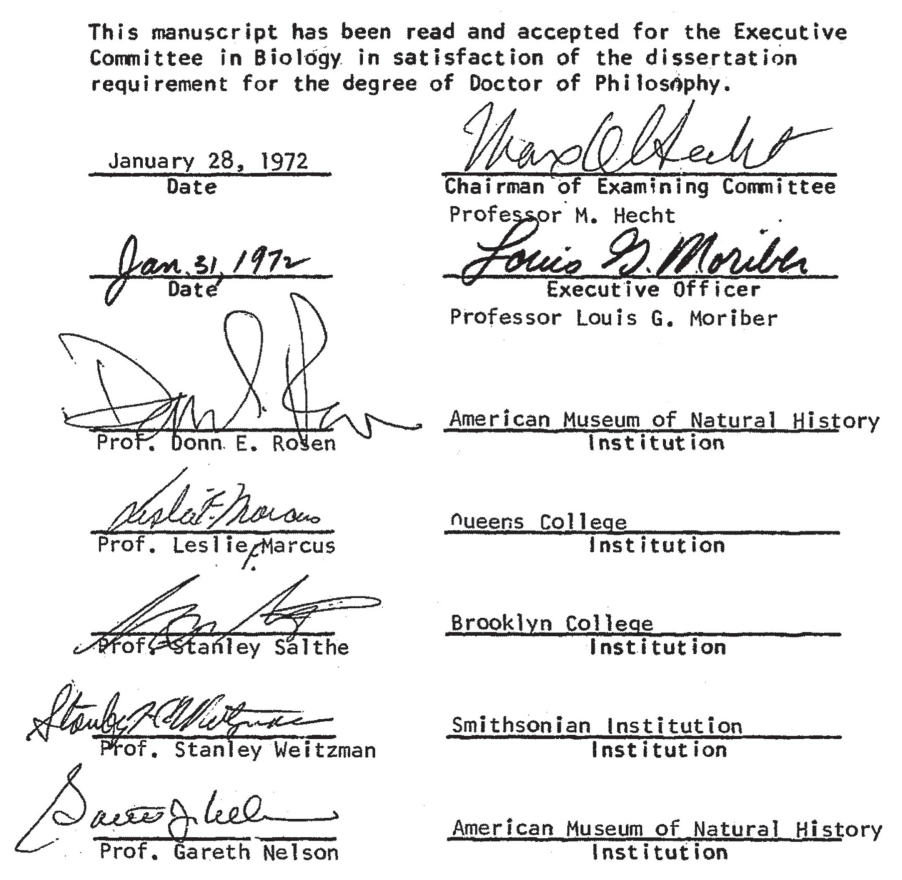

The City University of New York

Fig. 1. Title page and examiners' page of Baskin (1973).

\section{Material and Methods}

The unpublished Ph.D. Thesis of J. N. Baskin (Baskin, 1973 ) is critically and historically reviewed as to its impact on the development of the application of phylogenetic methods in neotropical ichthyology. The genesis of work is analyzed from the perspective of specific scientific and academic circumstances prevailing in the early 1970's. The hypotheses of relationships proposed in Baskin (1973) (S1 - Available only as online supplementary file accessed with the online version of the article at http://www.scielo. $\mathrm{br} / \mathrm{ni}$ ) are retrospectively evaluated from the perspective of developments in systematic research ensued during the intervening four decades of research on loricarioid phylogenetics, with emphasis on trichomycterids. Also discussed are the associated evidence and argumentation, derivative evolutionary inferences and resulting classificatory decisions, all from the perspective of the thennewly born phylogenetic paradigm.

\section{Results}

Although focused on trichomycterid relationships, Baskin (1973) also delved into questions of broader scope in catfish relationships. Among those was a list of siluriform synapomorphies which included some newly-observed characters and a discussion of previous diagnostic traits in a phylogenetic context. Baskin also provided a hypothesis on the monophyly and phylogeny of loricarioid catfishes. The group had been originally proposed in Peyer (1922), on the basis of the presence of odontodes, a trait unique among siluriforms plus the transverse segmentation pattern of the first pectoral-fin ray. Baskin confirmed the monophyly of the group, restricting its composition to the Nematogenyidae, Trichomycteridae, Callichthyidae, Scoloplacidae, Astroblepidae and Loricariidae, with their relationships hypothesized as a series of sequential sistergroups in that order. The work also rejected the possible inclusion in loricarioids of the Cetopsidae, Aspredinidae and the genus Phreatobius. Baskin reference to an intriguing "undescribed loricarioid", with a section devoted to a detailed discussion of its relevance to loricarioid relationships. He provided evidence that the undescribed taxon is a loricarioid, sister group to the Astroblepidae plus the Loricariidae. This mysterious taxon was later described as a new species, genus and family, Scoloplacidae (Bailey \& Baskin, 1976) and its phylogenetic position proposed in 1973 has been repeatedly corroborated (Howes, 1983; Schaefer, 1990; Sullivan et al., 2006).

The only part of the loricarioid tree of Baskin which has been somewhat contentious is the position of Nematogenys and Trichomycteridae. The two taxa have always been closely associated, most often in an expanded Trichomycteridae, but with the former sometimes in its own family, the Nematogenyidae (e.g., Eigenmann). Baskin for the first time proposed Nematogenys as sister 
group to all remaining loricarioids, an enticing hypothesis and one based on quite solid character evidence at the time. For example, Nematogenys was the only loricarioid known to have the plesiomorphic presence of an intercalarium, one of the ossicles in the Weberian chain. Later, the discovery of the "basal" trichomycterids - Trichogenes and copionodontines - changed that, since they too have an intercalarium, thus rendering the character homoplastic and its significance ambiguous in the scheme of loricarioid relationships. When such additional taxa and associated coded characters states are included in the analysis, the most parsimonious solution places Nematogenys as sister group to trichomycterids, rather than to all other loricarioids (de Pinna, 1992). The same hypothesis was presented in some pre-cladistic classifications (Eigenmann, 1918) and, in a phylogenetic context, independently by Mo (1991), without the benefit of those additional taxa, and later further corroborated by Diogo et al. (2006; but see also Datovo \& Bockmann, 2010:228-230 for a discussion of the latter). The shifting relative position of Nematogenys and trichomycterids is a problem of phylogenetic rooting. More precisely, it concerns the placement of the root of loricarioids. The two competing hypotheses are identical in an unrooted tree. When the root is positioned at the Nematogenys branch, that genus resolves as sister to the rest of the superfamily. If, instead, the loricarioid tree is rooted at the branch connecting trichomycterids and Nematogenys to the rest of terminals, then the two taxa turn out to be sister groups, forming a clade that is itself the sister group to the remainder of the superfamily. There has never been a proposal to root loricarioids anywhere else. This is likely due to the fact that Callichthyidae, Scoloplacidae, Astroblepidae and Loricariidae share an intenested set of extremely well-defined, unique characters not seen in any other siluriforms and a priori polarity considerations indirectly reject any rooting inside that assemblage. Of course, the root position relies on how loricarioids are related to the rest of the Siluriformes, a question not been entirely settled yet. Sullivan et al. (2006), based on rag1 and rag2 sequences, place loricarioids as sister group to all other siluriforms, the first proposal of a taxon other than for Diplomystidae in that position (Diplomystidae was moved up one step in the tree in that hypothesis). In the same analysis, the base of the loricarioid tree, with Nematogenys, trichomycterids and remaining loricarioids, is unresolved. The basal trichotomy is the result of two alternatives with sub-significant support: Nematogenys as sister group to all other loricarioids and Trichomycteridae as sister group to all other loricarioids (Nematogenys included). The latter hypothesis was never suggested previously and has little phenotypic support. Meanwhile, the alternative clade composed of Nematogenys plus trichomycterids was not supported by the data, but neither could it be rejected by Templeton and likelihood-based SH tests (Sullivan et al., 2006: 647). A similar basal trichotomy for loricarioids was previously expressed in Schaefer (1990).
Interestingly, Baskin himself noticed a number of apparently exclusive derived similarities between Nematogenys and trichomycterids, mostly in the form of clear-cut synapomorphies for trichomycterids seen in a less extreme or incipient state in Nematogenys. The apparent subjectivity in defining such intermediate character states probably led Baskin to discard such potential synapomorphies as too circumstantial to warrant use as solid evidence. Still, in several instances, the condition in Nematogenys are described as intermediate between that in trichomycterids and the one presumed for siluriforms. Such is the case with the pectoral-fin spine articulation exclusively with the cleithrum (p. 48); the reduction of the scapulo-coracoids (p. 49-50), and of the dorsohyal (p. 38). Although not mentioned, the lack of an adipose fin, given as a synapomorphy for Trichomycteridae, also characterizes the Nematogenyidae.

Much additional evidence probably remains to be uncovered relevant to the relationships of Nematogenys. A detailed study of the anatomy of the genus was never done and it seems likely that many informative phenotypic characters still await discovery. For example, Diogo et al. (2006) proposed two new autapomorphies for Nematogenys plus two new putative synapomorphies uniting it with Trichomycteridae on the basis of the comparative myology and osteology of the cephalic and pectoral regions. Also, molecular studies will certainly benefit from additional taxonomic sampling in that region of the tree. Sullivan et al. (2006), for example, included only four trichomycterid terminals. As happened with morphological data (de Pinna, 1992), the inclusion of "lower" trichomycterids such as Trichogenes and copionodontines will likely yield topological changes independently of new characters. Those taxa are long-branch breakers and as such may heavily impact results. An interesting taxonomic novelty which came to light since 1973 was the discovery of a fossil species of Nematogenys, N. cuivi, from Miocene deposits in Chile (Azpelicueta \& Rubilar, 1998). Although distinct from $N$. inermis, the fossil taxon is remarkably similar to its Recent congener in characters relevant for lower loricarioid relationships and casts no special light on the issue. The discovery is important, nonetheless, because it permits for the first time the establishment of a time frame for nematogenyid evolution, showing for example that the family was already differentiated before the uplift of the Andes.

Among the taxonomic discoveries that took place since 1973 , none is more relevant phylogenetically than that of the basal trichomycterid subfamilies Trichogeninae and Copionodontinae. Both were entirely unknown before their respective descriptions and came as complete surprise additions to trichomycterid diversity. The first of those was Trichogenes longipinnis, from two small isolated coastal creeks near the border between Rio de Janeiro and São Paulo in southeastern Brazil (Britski \& Ortega, 1983). Some years later, three Copionodontinae species were described from 
the headwaters of the Rio Paraguaçu basin in the Bahia, northeastern Brazil (de Pinna, 1992). The most remarkable fact about those discoveries is that they fit nearly perfectly what would be an archetype of a primitive trichomycterid. Of course, copionodontines and trichogenines are not really archetypes, having their own quite evident string of autapomorphies testimony to their long independent evolutionary history. Initially hypothesized as successive sister groups to all other trichomycterids (de Pinna, 1992), copionodontines and Trichogenes are in fact sister groups, forming a clade which is itself the sister group to the rest of the family (de Pinna, 1998; Datovo \& Bockmann, 2010). This was further corroborated with the recent discovery of a second species of Trichogenes, T. claviger, which displays conditions resembling some of the supposed synapomorphies for Copionodontinae (de Pinna et al., 2010). A separate subfamilial rank for Trichogenes and copionodontines was initially deemed necessary in face of the original hypothesis about their relationships (de Pinna, 1992). Now, with their position as sister groups, such classificatory decision becomes quite arbitrary and defensible only on grounds of nomenclatural stability (de Pinna, 1998). The discovery of T. claviger further bridged part of the gap, both phenotypic and geographic, between the two clades. Baskin (1973) gave a list of quite solid, homoplasy-free, phenotypic characters supportive of trichomycterid monophyly. Trichogenins and copionodontins display a nice mosaic of those, in an almost textbook example of phylogenetic intermediacy. For example, all trichomycterids lack a preopercular branch and part of the infraorbital canal (the latter not included as a character in Baskin) of the laterosensory canal system, except for those two basal taxa. Similarly, the sphenotic, pterotic and pterosphenoid are fused in all trichomycterids, but are fully separate in trichogenins and copionodontins.

Baskin divided all then-known trichomycterids into two major groups, one composed of the Trichomycterinae, Glanapteryginae and Sarcoglanidinae, called the "Trichomycterinae-group" and the other formed by the Tridentinae, Stegophilinae and Vandelliinae, called the "Vandelliinae-group". The Vandelliinae-group has been highly corroborated subsequently and seems beyond reasonable doubt (Costa \& Bockmann, 1993, 1994; de Pinna, 1998; Wosiacki, 2002; Datovo \& Bockmann, 2010; Fernández \& Schaefer, 2009). In fact, the perceived naturalness of that assemblage was quite explicit in older papers such as Eigenmann (1918). The Trichomycterinaegroup, contrastingly, is now considered paraphyletic. The collapse of that clade was the most profound change in trichomycterid relationships relative to Baskin (1973), although one which was not totally unforeseen, "the Trichomycterinae-group [...] is less well defined than the Vandelliinae-group, and it may turn out that it is not a monophyletic group" (p. 158). Costa \& Bockmann (1993, 1994) proposed the Glanapteryginae and Sarcoglanidinae as more closely related to the Vandelliinae-group than to the Trichomycterinae. The whole assemblage was called by Costa \& Bockmann the TSVSG clade, following the initials of each subfamily therein. The TSVSG clade has been subsequently corroborated in independent studies based on morphological (e.g., Datovo \& Bockmann, 2010) and molecular (Fernández \& Schaefer, 2009) data. The question that remains is: how to interpret the synapomorphies originally provided by Baskin for the Trichomycterinae-group? Some of the evidence is solid, for example the presence of an ossified third hypobranchial. In 1973, the character was considered somewhat ambiguous. Such uncertainty is perhaps reflected in the utilization (perhaps inadvertently) of both its presence and its absence as synapomorphies, the former for the Trichomycterinaegroup (p. 159) and the latter for the Vandelliinae-group (p. 147). There is little doubt now that the ossified condition is the apomorphic state at this level, because nematogenyids, trichogenins and copionodontins lack any ossification on the third hypobranchial (i.e., the element is entirely cartilaginous). Tracing the evolution of such details requires a taxonomically-representative analysis of trichomycterids that is especially dense in the lower portions of tree, with multiple Trichomycterus species, along with those of Ituglanis, Silvinichthys, Scleronema and the monotypic genera Bullockia, Eremophilus, Hatcheria and Rhizosomichthys. This was first carried out in Wosiacki (2002); a work which remains unpublished. Therein, the ossified third hypobranchial, for example, is shown to be a synapomorphy for all trichomycterids except trichogenins and copionodontins with a reversal distally in the clade formed by Tridentinae, Stegophilinae and Vandelliinae. Later, quite the same conclusion was reached by DoNascimiento (2013).

In close relation with the latter topic, the treatment of the subfamily Trichomycterinae in 1973 also deserves notice. Baskin laments the fact that "no evidence has been found to indicate that the genera included form a monophyletic group" (Baskin, 1973: 78). Indeed, the Trichomycterinae as traditionally composed appears nonmonophyletic. Some putative synapomorphies for the group have been proposed (Arratia, 1990), but based on limited taxonomic representation. Subsequent studies have shown that these characters have broader distributions across the Trichomycteridae (Datovo \& Bockmann, 2010: 235). As happened with the Trichomycterinae-group, some of those characters appear to be synapomorphies at a lower level subsequently reversed in more distal lineages of the family (Wosiacki, 2002; DoNascimiento, 2013). Some genera formally included in the Trichomycterinae, namely Scleronema and Ituglanis, have been proposed as more closely related to the TSVSG clade (see above) than to any of the other taxa in their former subfamily (Costa \& Bockmann, 1993). The evidence for such hypothesis has been shown to be ambiguous (Datovo \& Bockmann, 2010), though in a modified form they hold valid in other analyses (Wosiacki, 2002; DoNascimiento, 2013). The most evidently non-conforming portion of the "Trichomycterinae" is a 
clade of three minute species, Trichomycterus hasemani, $T$. johnsoni and T. anhanga which is certainly not closely related to any of the species in the subfamily (de Pinna, 1989; Wosiacki, 2002; Datovo \& Bockmann, 2010). The group (the "T. hasemani clade") seems to be related to the clade formed by Tridentinae, Stegophilinae and Vandelliinae (Wosiacki, 2002; DoNascimiento, 2013) and as such it requires allocation in a new genus and new subfamily. But more importantly, this small clade bears great comparative relevance as the closest relative of the highly-modified "parasitic" subfamilies and is a key element in elucidating the extraordinary evolution and diversification of that group. Finally, it must be added that the exclusion of the $T$. hasemani clade by itself does not resolve the phyletic status of the remaining taxa allocated in the Trichomycterinae. Wosiacki (2002) found that taxa from that subfamily form a ladder-like series of numerous successive sister groups to the TSVSG clade. Later, a unique myological specialization was found to be present in an assortment of trichomycterines (exclusive of T. hasemani) by Datovo \& Bockmann (2010). Naturally, as those authors noted (Datovo \& Bockmann, 2010: 238) the resolving power of a single character should not be overestimated and its effect on a globally most parsimonious hypothesis still needs to be evaluated.

The Sarcoglanidinae and Glanapteryginae are the subfamilies which have undergone the most dramatic expansion of known diversity since 1973. Both were then known exclusively from highly specialized representatives of their respective clades. Intervening years have seen the gradual discovery of successive sister groups to each subfamily. In glanapterygines, this process started with the genus Listrura, initially with two species (de Pinna, 1988) but eventually followed by a series of new species, all from Atlantic coastal drainages (de Pinna \& Wosiacki, 2002; Landim \& Costa, 2002; Villa-Verde \& Costa, 2006; VillaVerde et al., 2012, 2013). Quite the same process happened with sarcoglanidines, with the genera, Stauroglanis, Stenolicmus, Microcambeva and Ammoglanis discovered in quick succession during the later years of the twentieth century (de Pinna, 1989; de Pinna \& Starnes, 1990; Costa \& Bockmann, 1994; Costa, 1994). This is a stark contrast with the situation in 1973, when only Sarcoglanis and Malacoglanis were known. Of course, other than for the monophyly of the subfamily, there is little to compare between Baskin (1973) and more recent hypotheses of sarcoglanidine relationships. As might be expected some of sarcoglanidine synapomorphies proposed by Baskin are actually synapomorphies only for those two genera. Coincidentally, they are both the most distal terminals known in the subfamily and the first ones to be discovered and described (Myers \& Weitzman, 1966). Glanapterygines and sarcoglanidines are sister groups, a hypothesis first advanced in Baskin (1973) and which has been corroborated subsequently (Costa \& Bockmann, 1994; Fernández \& Schaefer, 2009; Datovo \& Bockmann, 2010). The increase in known diversity represented a phylogenetically gradual movement, fortuitously as it turned out, along both branches towards the common node of the clade. The most basal members of each clade are gradually less dissimilar as the diversity in the two subfamilies becomes better known towards their common ancestor. A point has already been reached where it is difficult to assign some species to one side or the other of the split. For example, it is probable that Ammoglanis pulex is actually a glanapterygine, and not an Ammoglanis or a sarcoglanidinae as originally described (de Pinna \& Winemiller, 2000). At the time of its description, specimens of the type species of Ammoglanis, A. diaphanus, were very rare and unavailable for detailed comparisons. Since then, more specimens have become available and preliminary comparisons are revealing details which cast doubt on previous interpretations of conditions in Ammoglanis (de Pinna \& Winemiller, 2000). My ongoing research indicates that $A$. pulex is a very basal species of glanapterygine. If that is confirmed, the species will require a new genus and obviously a reallocation into the Glanapteryginae.

Without a doubt, the trichomycterid subfamily where the least progress was made in the last 40 years is the Tridentinae. Knowledge about the group stands quite at the same stage as it was in 1973 and the information in Baskin's work remains to this date the most current source of phylogenetic information on the group. Although not all eight synapomorphies offered by Baskin for the Tridentinae remain valid in original form (DoNascimiento, 2013), there is little question about the monophyly of the subfamily. Other studies have corroborated that hypothesis, although none of these focused on tridentines specifically and their taxonomic representation is sparse (e.g., Wosiacki, 2002; Datovo \& Bockmann, 2010; DoNascimiento, 2013). In Baskin's tridentine tree, Miuroglanis is the sister group to remaining tridentines, with Tridentopsis the sister group to Tridensimilis plus Tridens. The same scheme, exclusive of Miuroglanis, was corroborated in DoNascimiento (2013). The genus Miuroglanis, incidentally, was a sort of mystery in tridentine taxonomy in 1973. The taxon had never been illustrated and was known only from a few type specimens, a situation which has recently changed ( $c f$. de Pinna, 2013: 155). Still, not only does the systematics of tridentines remain understudied, but even basic facts about their biology remain obscure. Most critically, it is not yet known whether they are semi-parasitic (scale-eating) or predators of small invertebrates. There is anecdotal but reliable information for the presence of both forms of feeding and it is possible that different species display distinct feeding behaviors. Certainly their biology is key to understanding the evolution of semi-parasitic feeding behavior of stegophilines and vandelliines. Despite the lack of directed research, material representative of tridentines now available in museums has grown substantially since 1973 and more detailed studies on tridentine systematics are in order.

Until recently, the Stegophilinae have been the object of little attention in the post-1973 era. There has been a 
complementary description of Haemomaster (Schmidt, 1985), a description of a new genus (Megalocentor de Pinna \& Britski, 1991), a survey of the species in Venezuela (DoNascimiento, 2001), a taxonomic revision of Homodiaetus (Koch, 2002), another of Ochmacanthus (Santos Neto, 2014) and a new species of Henonemus (DoNascimiento \& Provenzano, 2006). Monophyly of the Stegophilinae, initially based on a number of synapomorphies as per Baskin (1973) was stripped of some of its support as characters were found to apply to groups more or less inclusive than the limits of the subfamily (de Pinna \& Britski, 1991). In fact, the set of synapomorphies provided by Baskin for the Stegophilinae have undergone more changes than any of his other lists of derived characters. Still, the monophyly of the group was never in question, as subsequent authors have repeatedly reiterated it despite rather meager support (de Pinna \& Britski, 1991; Fernández \& Schaefer, 2009; Datovo \& Bockmann, 2010). It was only recently that substantial new progress came forth in DoNascimiento (2013) which is by far the most extensive contribution to date on stegophilines. That work is still in the process of publication, but a summary of its results was recently presented in DoNascimiento (2015). Comparing the details of stegophiline phylogeny in Baskin (1973) with that of subsequent authors is rather complicated because of changing definitions of genera and other taxonomic difficulties. For example, Baskin's notion of Stegophilus was not based on the type species of the genus, S. insidiosus, a fish still extremely rare and unavailable for anatomical study in the 1970's. Instead, his notion of Stegophilus was based on Henonemus, following a generic synonymy proposed by Miranda Ribeiro (1946) but later refuted (de Pinna \& Wosiacki, 2003; DoNascimiento, 2013).

The phylogenetic position of the monotypic genus Pareiodon is one of the boldest hypotheses introduced by Baskin for the parasitic forms. The taxon is indeed a strange chimaera of characters blending parasitic and non-parasitic forms. This is reflected in its assignment to a separate subfamily Pareiodontinae by most previous workers (e.g., Eigenmann, 1918). Baskin was the first to propose Pareiodon as a stegophiline. Not only that, the genus was considered as deeply interested within the subfamily, as sister group to a clade composed of Pseudostegophilus, Stegophilus, Homodiaetus and Apomatoceros. It is important to reiterate that Baskin's notion of Stegophilus was not based on the type species of the genus, but instead on Henonemus (see above). Regardless of that, Baskin was well aware that his proposed placement for Pareiodon required numerous hypotheses of character reversal, because the genus lacks some of the most evident synapomorphies for stegophilines: "More than the usual amount of evidence (and effort) is needed here to establish this as a monophyletic group including Pareiodon" (Baskin, 1973: 110). In context, his subsequent reference to a "most economical hypothesis" reveals that the decision on Pareiodon was ultimately based on parsimony considerations, albeit in the informal, non-quantitative manner often used at the time. The idea of Pareiodon as a highly modified stegophiline has been generally supported by subsequent studies. Wosiacki (2002) places the genus as sister group to the only stegophiline included in his analysis. Fernández \& Schaefer (2009), on the basis of mitochondrial and nuclear gene sequences, place Pareiodon as the sister group to Acanthopoma annectens (a taxon not examined by Baskin) and this clade, in turn, as the sister group of another clade composed of Pseudostegophilus, Apomatoceros and Henonemus. Pareiodon is deeply interested within the Stegophiline in the analysis of Datovo \& Bockmann (2010), with Parastegophilus and Pseudostegophilus as its successive sister groups (Acanthopoma was not examined). DoNascimiento (2013) places Pareiodon and Acanthopoma as closest relatives, with this clade being the sister group to Parastegophilus plus Pseudostegophilus. Despite differences of detail, it seems clear that Baskin's hypothesis was correct in general outline and that Pareiodon is actually a highly modified stegophiline. Baskin (1973: 177-178) proposed that the unique dentition and mouth structures of Pareiodon, as well as its small eyes, were indicative of feeding habits and general biology rather divergent from those in other stegophilines. Indeed, its carrionfeeding biology is unique in the subfamily. If phylogenetic hypotheses about its position are correct, such habits are derived from the rasping, scale- and mucus-eating habits of other species in the subfamily. If its sister group relationship with Acanthopoma is accepted, this offers further and fascinating opportunities for investigating possible intermediate conditions in behavior, physiology and functional morphology which might explain the transition between the feeding adaptations typical of stegophilines and the highly divergent carrion-feeding in Pareiodon.

As with other trichomycterid subfamilies, the hematophagous Vandelliinae were phylogenetically diagnosed for the first time in Baskin (1973). Among the synapomorphies newly identified by Baskin, some are unique across vast clades of bony fishes, such as the absence of a fifth ceratobranchial and the absence of hypobranchials two and three (Baskin, 1973: 87-89). Baskin's scheme for vandelliine relationships places Paracanthopoma as the sister group to all the rest of subfamily, with Paravandellia (=Branchioica) as sister group to Vandellia plus Plectrochilus. This scheme has been somewhat modified by Schmidt (1993), with Paravandellia and Paracanthopoma in switched positions. But Baskin's original hypothesis was once again recovered in Datovo \& Bockmann (2010). A third possibility, with Paracanthopoma and Paravandellia as sister groups was advanced in DoNascimiento (2013; results by Wosiacki, 2002 and Fernández \& Schaefer, 2009 are not pertinent to this question because not all relevant taxa were included). Thus, while monophyly of the Vandelliinae is undisputed, their basal relationships are controversial. Taxonomically, the Vandelliinae remains one of the least known trichomycterid subgroups. The latest valid nominal vandelliine species described was 
Paravandellia phaneronema (Miles, 1943). Such long elapsed time without taxonomic novelties, coupled with an extensive list of synonyms of some species such as Vandellia cirrhosa ( $c f$. de Pinna \& Wosiacki, 2003) may seem to indicate a group whose diversity is reasonably well-known. But the reality is exactly the opposite. Vandelliines are in fact the most extreme case of mismatch between actual and documented diversity among trichomycterids. But this diversity is currently hard to estimate properly, because of myriad problems of taxonomy. Concomitantly with the large number of undescribed forms, some common species have been described repeatedly. Without revisionary work it is virtually impossible to describe and organize that diversity. I have been conducting a revisionary work on the group for more than a decade. In some cases the number of species for specific genera, like Paracanthopoma will increase by an order of magnitude.

As of 1973, the only alleged record of any fossil trichomycterid was Propygidium primaevus (not included in Baskin), based on very fragmented material from the Eocene of the Rio Negro in Argentina (Bocchino, 1964) and never totally convincing as to its taxonomic placement. That material was later shown to be a representative of the Perciformes, not of a siluriform or a trichomycterid (Cione \& Torno, 1988). So, for most of its taxonomic history, the Trichomycteridae was a group without any fossil record. That situation only changed recently with the identification of disarticulated trichomycterid remains from the Pliocene of Monte Hermoso in Argentina (Bogan \& Agnolin, 2009). The opercular and interopercular bones as reported leave no doubt that the material is from trichomycterids. More specific determination of their taxonomic position may be possible, since the material is well-preserved, but will require detailed comparative study and considerable progress on the identification of individual bones. Still, once the Monte Hermoso material can be tied to more specific nodes in the phylogeny of the family, it will be an invaluable tool for dating specific branching points. Eventually this will allow for the first time a calibration of molecular divergence specific for the family and possibly the determination of an absolute time scale for trichomycterid diversification.

It is a curious coincidence that the highly distal taxa in the phylogeny of trichomycterids were described chronologically early in its taxonomic history and before more basal components. As a result, the initial diagnoses of subfamilies were based on markedly different taxa and extreme characteristics. With the subsequent discovery of less highly modified taxa, subfamilial limits have become progressively less well-defined, albeit still consistent phylogenetically. For example, the first glanapterygines described were Glanapteryx, Pygidianops and Typhlobelus, highly aberrant taxa in the clade (Myers, 1927, 1944). This led to a straightforward diagnosis of Glanapteryginae (established on the same occasion) based on characters such as the absence of dorsal fin. Later discoveries, mostly concentrated in genus Listrura (described in de Pinna,
1988) gradually blurred those initial clear cut diagnostic characters. For example, species of the glanapterygine genus Listrura have dorsal fins. Still, the subfamily is monophyletic, but its diagnostic characters are now details of internal anatomy difficult to inspect for a non-specialist. Initial distinguishing characters for glanapterygines are today considered synapomorphies for a smaller subgroup. The same happened with the subfamily Sarcoglanidinae. Here, the pattern of discovery of new taxa resulted in an inflated generic classification. Since the two first species discovered in the group were both highly distinctive and at the same time very different form one another, they were described as two monotypic genera, Sarcoglanis simplex and Malacoglanis gelatinosus (Myers \& Weitzman, 1966). Later discoveries in Sarcoglanidinae represented more basal lineages; usually sister groups to all, or most of the rest, of the subfamily. As such, they nomenclaturally required new genera in order to preserve the initial nuclear genera Malacoglanis and Sarcoglanis. Of course, the alternative would be to synonymize those two taxa, a move which has not appealed to any subsequent author given their pronounced degree of phenotypic divergence.

In sum, Baskin's work was, and remains, a source not only of original information and interpretations on catfish relationships and evolution, but also an inspirational piece of research. It is not often that one finds a scientific work where opposing views and competing hypotheses are presented candidly and without a trace of bias based on preferred preconceived notions. But this is what one finds in Baskin (1973) and that is the reason why I would recommend its reading not only to specialists, but also to any ichthyology student with a genuine interest in the study of biodiversity, its patterns, explanations and history of discoveries. In the early 1980's, still an undergraduate student but already taken by trichomycterid fascination, I got hold of a copy of Jon's thesis for the first time. In a single reading, the rich yet disorderly scenario painted by Steindachner, Regan, Miranda Ribeiro, Eigenmann and Myers acquired logical meaning. The structure underlying all that multiplicity of forms became clear. Both trichomycterid diversity and phylogenetic logic entered jointly in my mind as a powerfully coherent unit. Baskin (1973) was a landmark which imprinted on me the reality and intellectual gratification of systematics and phylogeny. Even though his work was obviously an impersonal piece of research, I consider it as an involuntary and somewhat temporally decoupled personal gift, granted to me in the twisted convergences of history. Some years later I had the pleasure of meeting Baskin the person, befriending him and over the years sharing opinions and ideas on our common interests - another privilege. The fact that his work is ultimately released through a Brazilian journal is particularly appropriate, in view of Jon Baskin's early association with Brazilian researchers (Fig. 2). It is therefore a great pleasure and honor to fulfill my role and to write this presentation. 


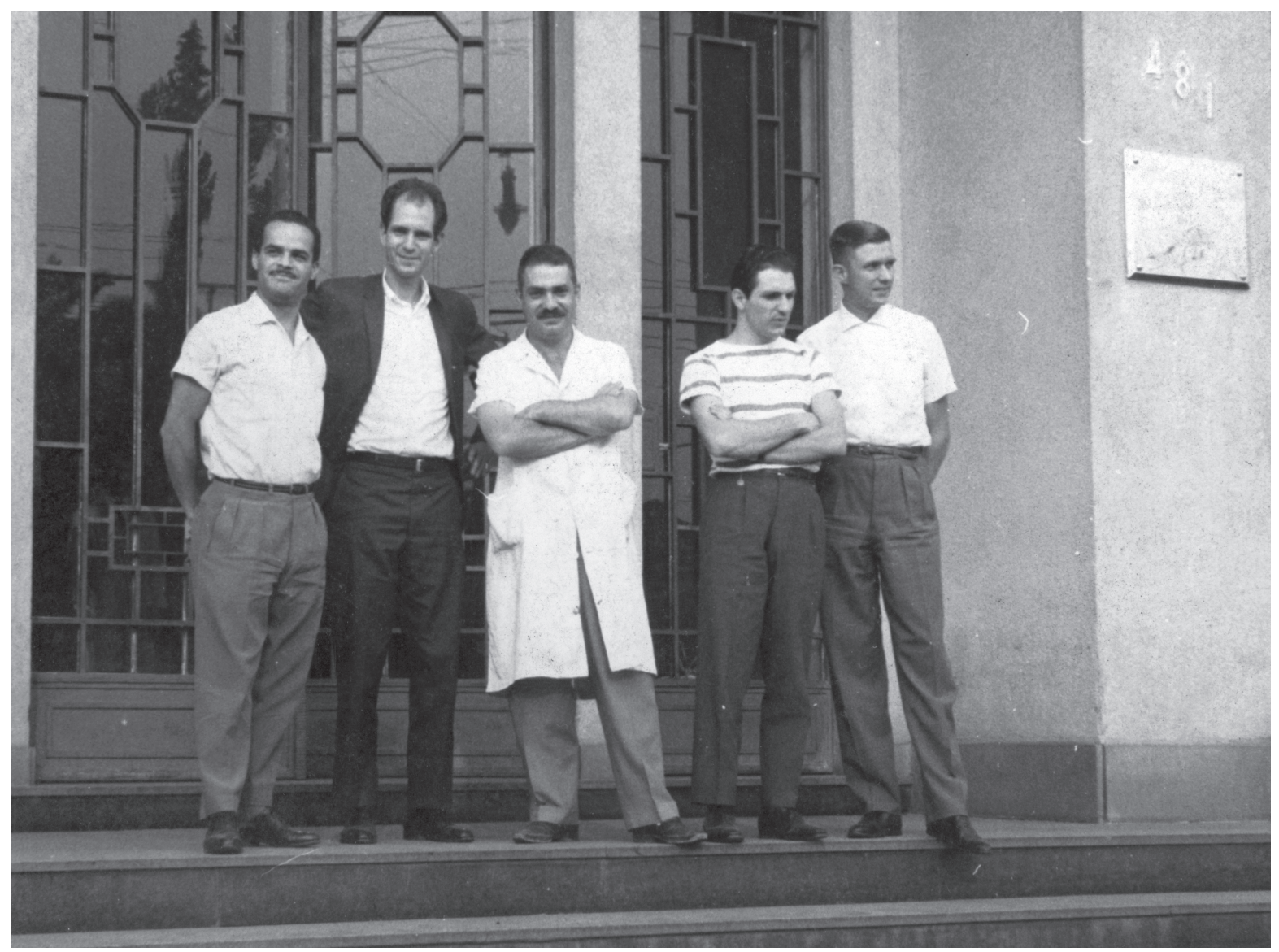

Fig. 2. From left to right: Naércio Menezes, Jonathan Baskin, Paulo Vanzolini, Almenor Tacla and Hans Reichardt at entrance of Museu de Zoologia da Universidade de São Paulo, São Paulo, in 1963.

\section{Acknowledgements}

Friendly reviews and suggestions by F. Bockmann, F. Dagosta, A. Datovo, C. DoNascimiento, L. Malabarba and R. Vari are gratefully acknowledged. Long-term financial support for the author's research is provided by CNPq, FAPESP and CAPES. Part of this paper was written during a sabbatical tenure at the Muséum National d'histoire Naturelle, Paris. I thank the generosity and helpfulness of René Zaragueta-Bagils and Guillaume Lecointre in making that arrangement possible.

\section{References}

Arratia, G. 1990. The South American Trichomycterinae (Teleostei: Siluriformes), a problematic group. Pp. 395403. In: Peters, G. \& R. Hutterer (Eds.). Vertebrates in the Tropics. Bonn, Museum Alexander Koenig.

Azpelicueta, M. M. \& A. Rubilar. 1998. A Miocene Nematogenys (Teleostei: Siluriformes: Nematogenyidae) from South-Central Chile. Journal of Vertebrate Paleontology, 18: 475-483.

Bailey, R. M. \& J. N. Baskin, 1976. Scoloplax dicra, a new armored catfish from the Bolivian Amazon. Occasional Papers of the Museum of Zoology, University of Michigan, 674: 1-14.
Baskin, J. N. 1973. Structure and relationships of the Trichomycteridae. Unpublished Ph.D. Dissertation, City University of New York, New York, 389p.

Bocchino, A. 1964. Sobre un Pygidiidae (Pisces, Siluriformes) del Eoceno del Río Negro. Ameghiniana, 3: 185-189.

Bogan, S. \& F. L. Agnolin. 2009. Primer registro fósil de la familia Trichomycteridae (Teleostei: Siluriformes: Plioceno) en la formación Monte Hermoso, Argentina. Revista del Museo Argentino de Ciencias Naturales, 11: 193-198.

Britski, H. A. \& H. Ortega. 1983. Trichogenes longipinnis, novo gênero e espécie de Trichomycterinae do sudeste do Brasil (Pisces, Siluriformes). Revista Brasileira de Zoologia, 1: 211-216.

Cione, A. L. \& A. Torno. 1988. Assignment of the bony fish "Propygidium primaevus" (a supposed siluriform from the tertiary of Patagonia) to the order Perciformes. Journal of Paleontology, 62: 656-657.

Costa, W. J. E. M. 1994. A new genus and species of Sarcoglanidinae (Siluriformes: Trichomycteridae) from the Araguaia basin, central Brazil, with notes on subfamilial phylogeny. Ichthyological Exploration of Freshwaters, 5: 207216.

Costa, W. J. E. M. \& F. A. Bockmann. 1993. Un nouveau genre néotropical de la famille des Trichomycteridae (Siluriformes: Loricarioidei). Revue Française d'Aquariologie, 20: 43-46. 
Costa, W. J. E. M. \& F. A. Bockmann. 1994. A new genus and species of Sarcoglanidinae (Siluriformes: Trichomycteridae) from southeastern Brazil, with a reexamination of subfamilial phylogeny. Journal of Natural History, 28: 715-730.

Datovo, A. \& F. A. Bockmann. 2010. Dorsolateral head muscles of the catfish families Nematogenyidae and Trichomycteridae (Siluriformes: Loricarioidei): comparative anatomy and phylogenetic analysis. Neotropical Ichthyology, 8: 193-246.

Diogo, R., M. Chardon \& P. Vanderwalle. 2006. On the osteology and myology of the cephalic region and pectoral girdle of Nematogenys inermis (Ghichenot, 1848), with comments on the autapomorphies and phylogenetic relationships of the Nematogenyidae (Teleostei : Siluriformes). Belgian Journal of Zoology, 136: 15-24.

DoNascimiento, C. L. 2001. Las especies de la subfamilia Stegophilinae (Siluriformes, Trichomycteridae) y su distribución geográfica en Venezuela. Unpublished Bachelor's Dissertation, Universidad Central de Venezuela, Caracas, 154p.

DoNascimiento, C. L. 2013. Sistemática y relaciones filogenéticas de la subfamilia de bagres parásitos Stegophilinae (Siluriformes, Trichomycteridae). Unpublished Ph.D. Thesis, Facultad de Ciencias, Universidad Central de Venezuela, Caracas. 341p.

DoNascimiento, C. 2015. Morphological evidence for the monophyly of the subfamily of parasitic catfishes Stegophilinae (Siluriformes, Trichomycteridae) and phylogenetic diagnoses of its genera. Copeia, 103: 933-960.

DoNascimiento, C. \& F. Provenzano. 2006. The genus Henonemus (Siluriformes: Trichomycteridae) with a description of a new species from Venezuela. Copeia, 2006: 198-205.

Eigenmann, C. H. 1918. The Pygidiidae, a family of South American catfishes. Memoirs of the Carnegie Museum, 7: 259-398.

Farris, J. S. 1968. The evolutionary relationships between the species of the killifish genera Fundulus and Profundulus (Teleostei: Cyprinodontidae). Unpublished Ph.D. Dissertation, University of Michigan, Ann Arbor, 73p.

Fernández, L. \& S. A. Schaefer. 2009. Relationships among the Neotropical candirus (Trichomycteridae, Siluriformes) and the evolution of parasitism based on analysis of mitochondrial and nuclear gene sequences. Molecular Phylogenetics and Evolution, 52: 416-423.

Hennig, W. 1966. Phylogenetic Systematics. Urbana, University of Illinois Press, 263p.

Howes, G. J. 1983. The cranial muscles of loricarioid catfishes, their homologies and value as taxonomic characters (Teleostei: Siluroidei). Bulletin of the British Museum (Natural History), Zoology, 45: 309-345.

Hull, D. L. 1988. Science as a Process: an evolutionary account of the social and conceptual development of science. Chicago, University of Chicago Press, 600p.

Koch, W. R. 2002. Revisão taxonômica do gênero Homodiaetus (Teleostei, Siluriformes, Trichomycteridae). Iheringia, Série Zoologia, 92: 33-46.
Landim, M. I. \& W. J. E. M. Costa. 2002. Listrura tetraradiata (Siluriformes: Trichomycteridae): a new glanapterygine catfish from the southeastern Brazilian coastal plains. Copeia, 2002: 152-156.

Mayr, E. 1969. Principles of Systematic Zoology. New York, McGraw Hill.

Mayr, E. 1974. Cladistic analysis or cladistic classification? Zeitschrift fur Zoologische systematic und Evolutionsforschung, 12: 94-128.

Miles, C. 1943. Estudio economico y ecologico de los peces de agua dulce del Valle del Cauca. Cali, Publicaciones de la Secretaria de Agricultura y Fomento del Departamento de Valle del Cauca. 99p.

Miranda Ribeiro, P. de. 1946. Notas para o estudo dos Pygidiidae Brasileiros (Pisces - Pygidiidae - Stegophilinae), I. Boletin do Museu Nacional, Zoologia (N. S.), 58: 1-20.

Mo, T. 1991. Anatomy, relationships and systematics of the Bagridae (Teleostei : Siluroidei) with a hypothesis of siluroid phylogeny. Theses Zoologicae, 17: 1-216

Myers, G. S. 1927. Descriptions of new South American fresh-water fishes collected by Dr. Carl Ternetz. Bulletin of the Museum of Comparative Zoology, 68: 107-135.

Myers, G. S. 1944. Two extraordinary new blind nematognath fishes from the rio Negro, representing a new subfamily of Pygidiidae, with a rearrangement of the genera of the family, and illustrations of some previously described genera and species from Venezuela and Brazil. Proceedings of the California Academy of Sciences, 23: 591-602.

Myers, G. S. \& S. H. Weitzman. 1966. Two remarkable new trichomycterid catfishes from the Amazon basin in Brazil and Colombia. Journal of Zoology, 149: 277-287.

Nelson, G. J. 1969. Infraorbital bones and their bearing on the phylogeny and geography of osteoglossomorph fishes. American Museum Novitates, 2394: 1-38.

Nelson, G. J. 2009. Cladistics - Search for the sister group. Pp. 8082. In: Milner, R. (Ed.). Darwin's Universe, Evolution from A to Z. Berkeley, University of California Press.

Peyer, B. 1922. Über die Flossenstacheln der Welse und Panzerwelse, sowie des Karpfens. Morphologisches Jahrbucher, 51: 493-554.

de Pinna, M. C. C. 1988. A new genus of trichomycterid catfish (Siluroidei, Glanapteryginae), with comments on its phylogenetic relationships. Revue Suisse de Zoologie, 95: 113-128.

de Pinna, M. C. C. 1989. A new sarcoglanidine catfish, phylogeny of its subfamily, and an appraisal of the phyletic status of the Trichomycterinae (Teleostei, Trichomycteridae). American Museum Novitates, 2950: 1-39.

de Pinna, M. C. C. 1992. A new subfamily of Trichomycteridae (Teleostei, Siluriformes), lower loricarioid relationships and a discussion on the impact of additional taxa for phylogenetic analysis. Zoological Journal of the Linnean Society, 106: 175-229.

de Pinna, M. C. C. 1998. Phylogenetic relationships of Neotropical Siluriformes: historical overview and synthesis of hypotheses. Pp. 279-330. In: Malabarba, L. R., R. E. Reis, R. P. Vari, Z. M. S. Lucena \& C. A. S. Lucena (Eds.). Phylogeny and Classification of Neotropical Fishes. Porto Alegre, Edipucrs. 
de Pinna, M. C. C. 2013. Trichomycteridae. Pp.142-179. In: de Queiroz, L. J., G. Torrente-Vilara, W. M. Ohara, T. H. Silva Pires, J. Zuanon \& C. R. Costa Doria (Eds.). Peixes do Rio Madeira, Volume 2. São Paulo, Santo Antônio Energia.

de Pinna, M. C. C. \& H. A. Britski. 1991. Megalocentor, a new genus of parasitic catfish from the Amazon basin: the sister group of Apomatoceros (Trichomycteridae: Stegophilinae). Ichthyological Exploration of Freshwaters, 2: 113-128.

de Pinna, M. C. C., J. L. Helmer, H. A. Britski \& L. R. Nunes. 2010. A new species of Trichogenes from the rio Itapemirim drainage, southeastern Brazil, with comments on the monophyly of the genus (Siluriformes: Trichomycteridae). Neotropical Ichthyology, 8: 707-717.

de Pinna, M. C. C. \& W. C. Starnes. 1990. A new genus and species of Sarcoglanidinae from the Río Mamoré, Amazon Basin, with comments on subfamilial phylogeny (Teleostei, Trichomycteridae). Journal of Zoology, 222: 75-88.

de Pinna, M. C. C. \& K. O. Winemiller. 2000. A new species of Ammoglanis (Siluriformes: Trichomycteridae) from Venezuela. Ichthyological Exploration of Freshwaters, 11: 255-264.

de Pinna, M. C. C. \& W. B. Wosiacki. 2002. A new interstitial catfish of the genus Listrura from southern Brazil (Siluriformes: Trichomycteridae: Glanapteryginae). Proceedings of the Biological Society of Washington, 115: 720-726.

de Pinna, M. C. C. \& W. Wosiacki. 2003. Family Trichomycteridae (Pencil or parasitic catfishes). Pp. 270-290. In: R. E. Reis, S. O. Kullander y C. J. Ferraris Jr. (Eds.). Checklist of the freshwater fishes of South and Central America. Porto Alegre, Edipucrs.

Rosen, D. E. 1972. Origin of the characid fish genus Bramocharax and a description of a second, more primitive, species in Guatemala. American Museum Novitates, 2500: 1-21.

Santos Neto, C. 2014. Sistemática do gênero Ochmacanthus: um grupo de bagres neotropicais lepidófagos (Teleostei: Siluriformes: Trichomycteridae). Unpublished MSc. Dissertation, Museu de Zoologia da Universidade de São Paulo. 221p.
Schaefer, S. A. 1990. Anatomy and relationships of the scoloplacid catfishes. Proceedings of the Academy of Natural Sciences of Philadelphia, 142: 167-210.

Schmidt, R. E. 1985. New distribution records and complementary description of Haemomaster venezuelae (Siluriformes: Trichomycteridae), a rare and poorly known fish from northern South America. Studies on the Neotropical Fauna and Environment, 20: 93-96.

Schmidt, R. E. 1993. Relationships and notes on the biology of Paracanthopoma parva (Pisces: Trichomycteridae). Ichthyological Exploration of Freshwaters, 4: 185-191.

Simpson, G. G. 1981. Exhibit dismay. Nature, 290: 286.

Sullivan, J. P., J. G. Lundberg \& M. Hardman. 2006. A phylogenetic analysis of the major groups of catfishes (Teleostei: Siluriformes) using rag1 and rag2 nuclear gene sequences. Molecular Phylogenetics and Evolution, 41: 636-662.

Villa-Verde, L. \& W. J. E. M. Costa. 2006. A new glanapterygine catfish of the genus Listrura (Siluriformes: Trichomycteridae) from the southeastern Brazilian coastal plains. Zootaxa, 1142: 43-50.

Villa-Verde, L., J. Ferrer \& L. R. Malabarba. 2013. A New species of Listrura from Laguna dos Patos system, Brazil: the southernmost record of the Glanapteryginae (Siluriformes: Trichomycteridae). Copeia, 2013: 641-646.

Villa-Verde, L., H. Lazzarotto \& S. M. Q. Lima. 2012. A new glanapterygine catfish of the genus Listrura (Siluriformes: Trichomycteridae) from the southeastern Brazil, corroborated by morphological and molecular data. Neotropical Ichthyology, 10: 527-538.

Wosiacki, W. B. 2002. Estudo das relações filogenéticas de Trichomycterinae (Teleostei, Siluriformes, Trichomycteridae) com uma proposta de classificação. Unpublished Ph.D. Dissertation, Universidade de São Paulo, São Paulo, 324p.

Submitted August 27, 2015 Accepted March 02, 2016 by Luiz Malabarba 